\title{
STUDY ON THE EFFECTS OF ARTIFICIAL FLOOD FOR RIVER CHANNEL DISTURBANCE IN THE MAINTENANCE OF OLD WATERCOURSES
}

\author{
Keizo SUMITOMO ${ }^{1}$, Yasuharu WATANABE ${ }^{2}$, Norihiro IZUMI ${ }^{3}$, \\ Satomi YAMAGUCHI ${ }^{4}$ and Hideaki YOKOHAMA ${ }^{5}$ \\ ${ }^{1}$ Member of JSCE, Docon Co., Ltd. \\ (Atsubetu Chuou 1-jou 5-choume 4-1, Atsubetu-ku Sapporo, Hokkaido 004-8585, Japan) \\ E-mail:ks1578@docon.jp \\ ${ }^{2}$ Member of JSCE, Professor, Kitami Institute of Technology (165 Kouen-cho Kitami, Hokkaido 090-8507, Japan) \\ E-mail: y-watanb@mail.kitami-it.ac.jp \\ ${ }^{3}$ Member of JSCE, Professor, Faculty of Engineering, Hokkaido University \\ (North 13 West 8, Kita-ku, Sapporo 060-8628, Japan) \\ E-mail:nizumi@eng.hokudai.ac.jp \\ ${ }^{4}$ Member of JSCE, Civil Engineering Research Institute for Cold Region \\ (3-1-43 Hiragishi Ichijo, Toyohira-ku Sapporo, Hokkaido 062-8602, Japan) \\ E-mail: kawamura-s@ceri.go.jp \\ ${ }^{5}$ Hokkaido Regional Development Bureau (Nishi 4-jou Minami 8-choume Obihiro, Hokkaido 080-8585, Japan) \\ E-mail: yokohama-h29k@mlit.go.jp
}

\begin{abstract}
The effect of artificial flood on river channel disturbance is clarified quantitatively using the results of field observations and numerical simulations. Based on the prediction of positive impacts expected in the maintenance of ancient watercourses, channel changes were analyzed using river bed calculations during the flood of August 2016, which was the largest available scale. Results showed that the vegetative area lost owing to the flood tended to be larger along the old watercourse than they were in the current channel, and was also noticeable in the section where the old watercourse was actively maintained by excavation. This research has demonstrated that the maintenance of the old watercourse has positive impact on the restoration of gravel bars by promoting channel changes during floods.
\end{abstract}

Key Words: Satsunai River, artificial flood, distributary, river channel disturbance

\section{INTRODUCTION}

The Satsunai River, the first tributary of the firstclass Tokachi River, was characterized by multiple channels with wide gravel bars. The effects of a dramatic decrease in the annual maximum river discharges between 2006 and 2010 and other factors significantly accelerated forestation in the river channels. ${ }^{1), 2)}$ River channels were stabilized, and the size of gravel bars was reduced quickly. Fig. 1 shows the changes in the forested and gravel bar areas over the years, and Photo 1 shows the progress of forestation.

On the basis of above status, for the purpose of recovery of gravel bars in the Satsunai River, since 2012, artificial floods have been implemented from Satsunai River dam with maximum discharge of $120 \mathrm{~m}^{3} / \mathrm{s}$, an equivalent of probability scale of $1 / 1$ at the end of June. ${ }^{1), 2)}$

Yamaguchi et al. $^{3)}$ confirmed that during a flood of probability scale of 1/20 in September 2011, in the

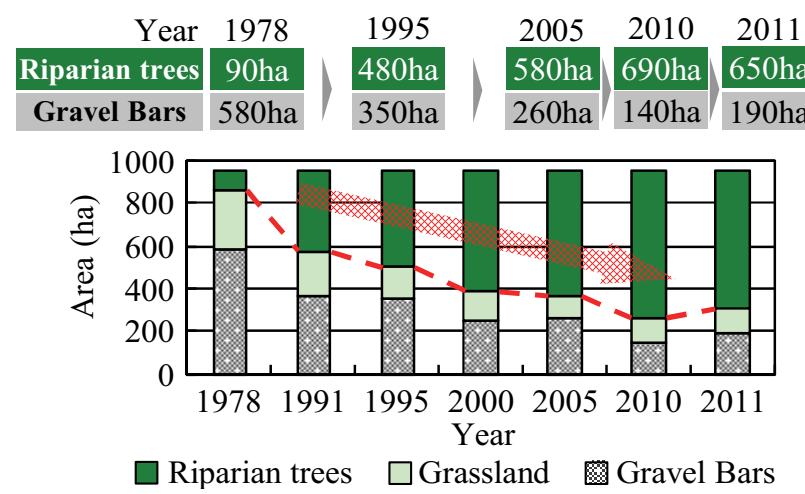

Fig.1 The secular changes in the areas of vegetated bars and gravel bars at upper reach of the Satsunai river.

area where the old watercourse in the forested area, a large channel disturbance was observed in an area where the river bed heights at the bifurcation of the current and old channels were about the same height; meanwhile, in the area where the inflow section of 
the old watercourse was blocked due to sediment deposition, only small-scale disturbance was seen. They noted this point and showed that by selecting a location where the river bed slope in the lower side of the pool and connecting it to the old watercourse by excavation, they were able to restore the old watercourse efficiently.

Shimizu et al., ${ }^{4), 5)}$ on the other hand, revealed that suppressed forestation occurred after an excavation in the stabilized sandbar of the Watarase River, inducing a large flood and thereby flood disturbance.

In August, 2016, the largest existing scale of flood in the Satsunai River resulted in some increase in the gravel bar areas and the loss of river vegetation, but there was a significant difference in terms of the scale of vegetative loss between the current and the old ones.

Based on the above discussion, considering applying the ideas to other rivers going forward, when deciding the location where the old watercourse can be restored efficiently, channel trend was analyzed and consideration was given to the scale of excavation required for the restoration of old watercourses. We predicted the expected positive effects by maintaining the old watercourse based on the calculation of river bed variations. Additionally, we analyzed the status changes in the river channel caused by the flood in August 2016 and calculated the loss of vegetated area along the current and the old watercourses and evaluated the positive effects by maintaining the old water-
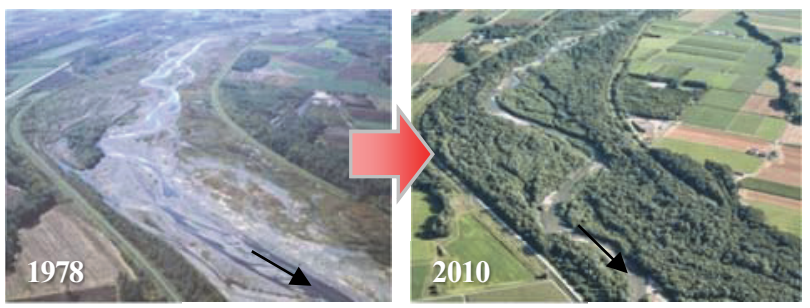

Photo1 Thick tree growth and established watercourses. course.

The purpose of this paper is to investigate the effects of the maintenance of the old watercourse by artificial flood, which then leads to recovery of gravel bars.

\section{EFFICIENT METHODS TO RESTORE AND STABILIZE THE OLD WATER- COURSES}

The stabilization of the current watercourse is greatly influenced by the loss of the branched flow. ${ }^{6}$ ) Thus, at the upper reach section of the Satsunai River, the sediment deposition was excavated at the inflow section of the old watercourse at the normal water level between one to four locations since 2013, and a total of nine project areas were installed where the current watercourse was branched and connected to the old watercourse. Locations, channel characteristics, annual maximum discharges, and excavation diagrams are shown in Fig. 2 to Fig. 4. Excavation conditions were uniform in project areas, but based on the 2014 survey, lower reach project area D showed less inflow into the old watercourse.

The trend in channel plane and stream profile for both the E project area where the inflow into the old watercourse was great and the flood in August 2014 changed the channel, and the D project in the lower reach area where such change was small were confirmed by the existing aerial photographs and the laser profiler data (hereinafter LP) taken in 2013. Fig. 5 shows the channel changes and stream profiles at each location.

The channels with multiple bars alternately exhibit wider (anti-nodes) and narrower (nodes) sections due to erosion in the flow direction. ${ }^{7)}$ Fig. 5 shows that at nodes, channel changes are small in cross-sectional direction while anti-nodes located in the lower direction from the node and channel change greatly. Nodes

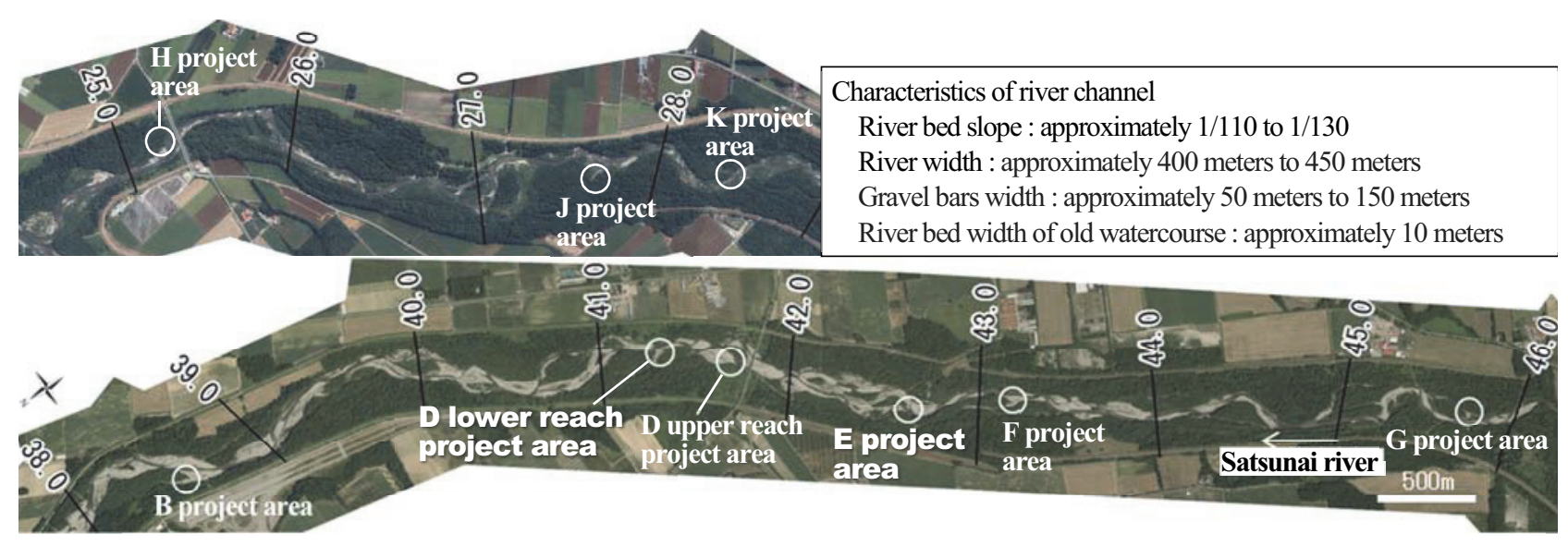

Fig.2 Location map of 9 project areas and characteristics of river channel. 
and anti-nodes seen in channel changes are classified as pool or riffle. A node shown in the river bed close to the level is classified as a pool, while an anti-node seen lower from the pool at 1/110 slope is classified as a riffle. The stream profile in Fig. $\mathbf{5}$ shows that the E project area is immediately below the node and the D lower reach project area is at the node respectively connected to the old watercourse. When the river bed slope is gradual, the proportional flow volume branched into is significantly reduced ${ }^{3)}$ and therefore the $\mathrm{D}$ lower reach project area with the river bed slope as it is, the flow into the old watercourse is probably reduced.

In order to efficiently restore the old watercourse, it is important to understand the detailed stream profile and connect the flow into the old watercourse imme-

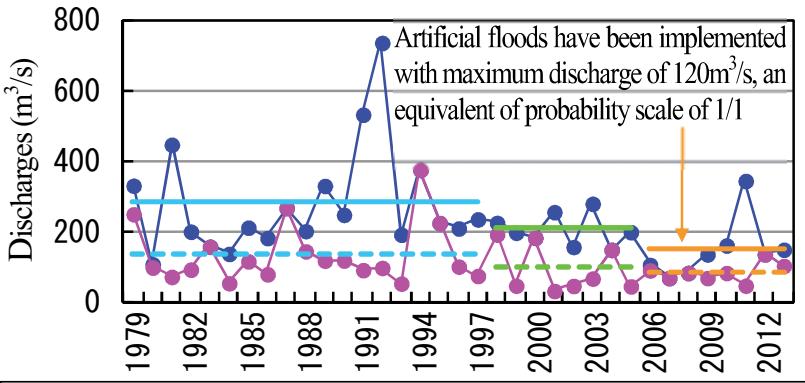

\begin{tabular}{|c|c|}
\hline - Annual maximum discharges & - - Maximum snowmelt discharges \\
Average from 1979 to 1997 & - - - Average from 1979 to 1997 \\
Average from 1998 to 2005 & - - - Average from 1998 to 2005 \\
Average from 2006 to 2013 & - - - Average from 2006 to 2013
\end{tabular}

Fig.3 The secular changes in annual maximum discharges and maximum snowmelt discharges at upper reach of the Satsunai river.

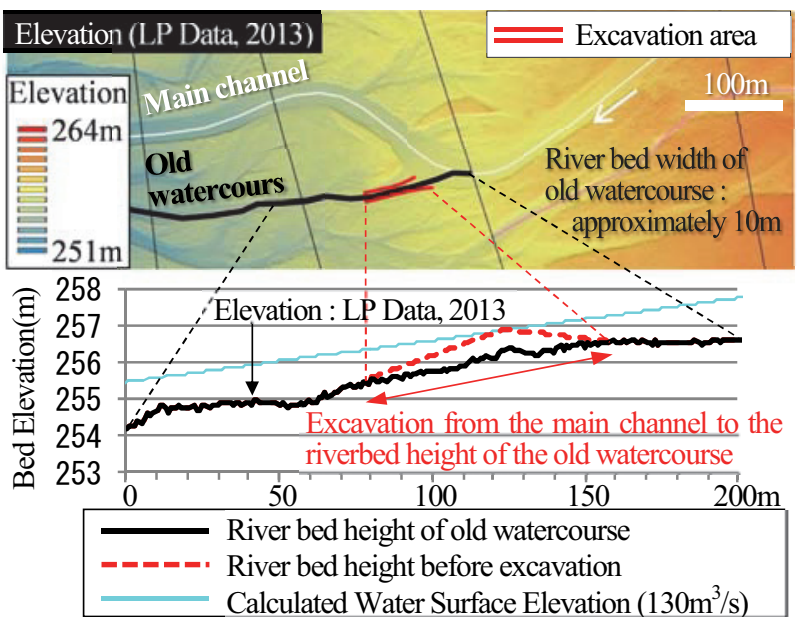

Fig.4 Standard excavation diagrams (Example of E project area).
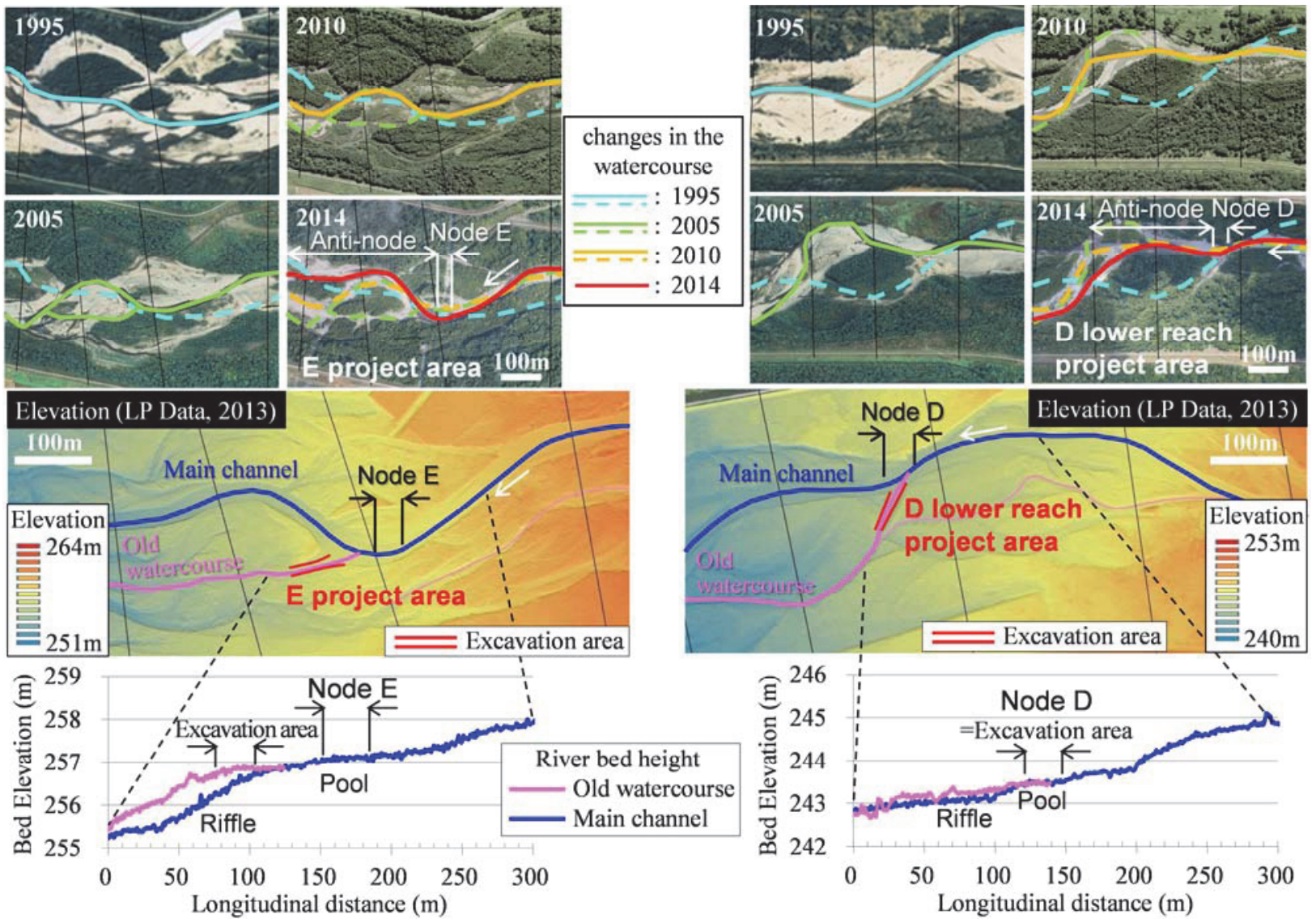

Fig.5 The trend in channel plane and stream profile for both E project area where the inflow into the old watercourse and D project in the lower reach area where such change was small. 
diately below a node at steep slope.

However, understanding the longitudinal characteristics of pools and riffles through regular crosssectional measurements implemented at regular interval of approximately $200 \mathrm{~m}$ only is challenging, and having a detailed stream profile by surveying all rivers is not an easy task. Therefore, if multiple channels are to be restored efficiently, it is important to select excavation locations at the old watercourse connections, to be confirmed using existing aerial photographs, for the distribution of old watercourses along with nodes and anti-nodes locations and the survey of stream profile with particular attention to the upper and lower sections of nodes.

\section{EVALUATION ON THE MAINTE- NANCE OF THE OLD WATER- COURSE BY ARTIFICIAL FLOODS}

Due to status changes ${ }^{3)}$ after the September Flood in 2011 in a large-scale channel disturbance, maintaining the old watercourse is considered necessary during floods. Therefore, the effects of artificial floods after excavation to connect to the old watercourse were discussed based on river bed variation,

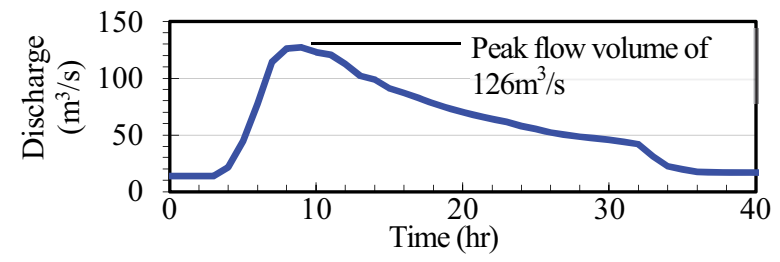

Fig.6 The hydrograph of the artificial flood in 2013. using iRIC Nays2D 4.2. $\left.{ }^{8}\right)$

\section{(1) Simulated river bed variation status by arti- ficial floods}

Prior to forecast calculation, river bed variations were replicated prior to and after the artificial flood in 2013. LP data prior to and after the flood were then compared for replicability confirmation purposes. Calculation conditions are shown in Table 1 and discharging hydrograph is shown in Fig. 6. Grain diameter of bed material is homogenous and diameters are set at $59.2 \mathrm{~mm}, 70.9 \mathrm{~mm}$, and $112.4 \mathrm{~mm}$ at $\mathrm{KP}$ 41,42 , and 43 respectively based on the 2012 survey results of 2012 at $60 \%$ diameter. Based on the three diameters calculated, grain diameter of $59.2 \mathrm{~mm}$ was the most replicable.

Fig. 7 shows the bed variations before and after the artificial flood when the bed material is $59.2 \mathrm{~mm}$ in

Table 1 The calculation conditions.

\begin{tabular}{|c|c|}
\hline Item & Condition \\
\hline Discharge (Fig. 6) & $\begin{array}{l}\text { Recorded hydrograph of the artificial } \\
\text { flood in } 2013\end{array}$ \\
\hline Bed elevation & $\begin{array}{l}\text { Observed data before the artificial flood } \\
\text { in June } 2013 \text { (Laser Profiler Data) }\end{array}$ \\
\hline Grid size for calculation & $5 \mathrm{~m} \times 5 \mathrm{~m}$ \\
\hline Calculation section & From KP41 to KP43 \\
\hline Vegetated area & $\begin{array}{l}\text { The area was deciphered by the aerial } \\
\text { photograph taken in June } 2013 \text {. }\end{array}$ \\
\hline Manning coefficient & $\begin{array}{l}\text { Calculated by the Manning-Strickler } \\
\text { formula which uses bed material size. } \\
\text { ( } 0.07 \text { is used at vegetated zone) }\end{array}$ \\
\hline Bed material size & $\begin{array}{l}\text { (0) Case } 1: 59.2 \mathrm{~mm} \text {, Case } 2: 70.9 \mathrm{~mm} \text {, } \\
\text { Case } 3: 112.4 \mathrm{~mm}\end{array}$ \\
\hline Bed-load transport rate & Ashida-Michiue formula \\
\hline
\end{tabular}

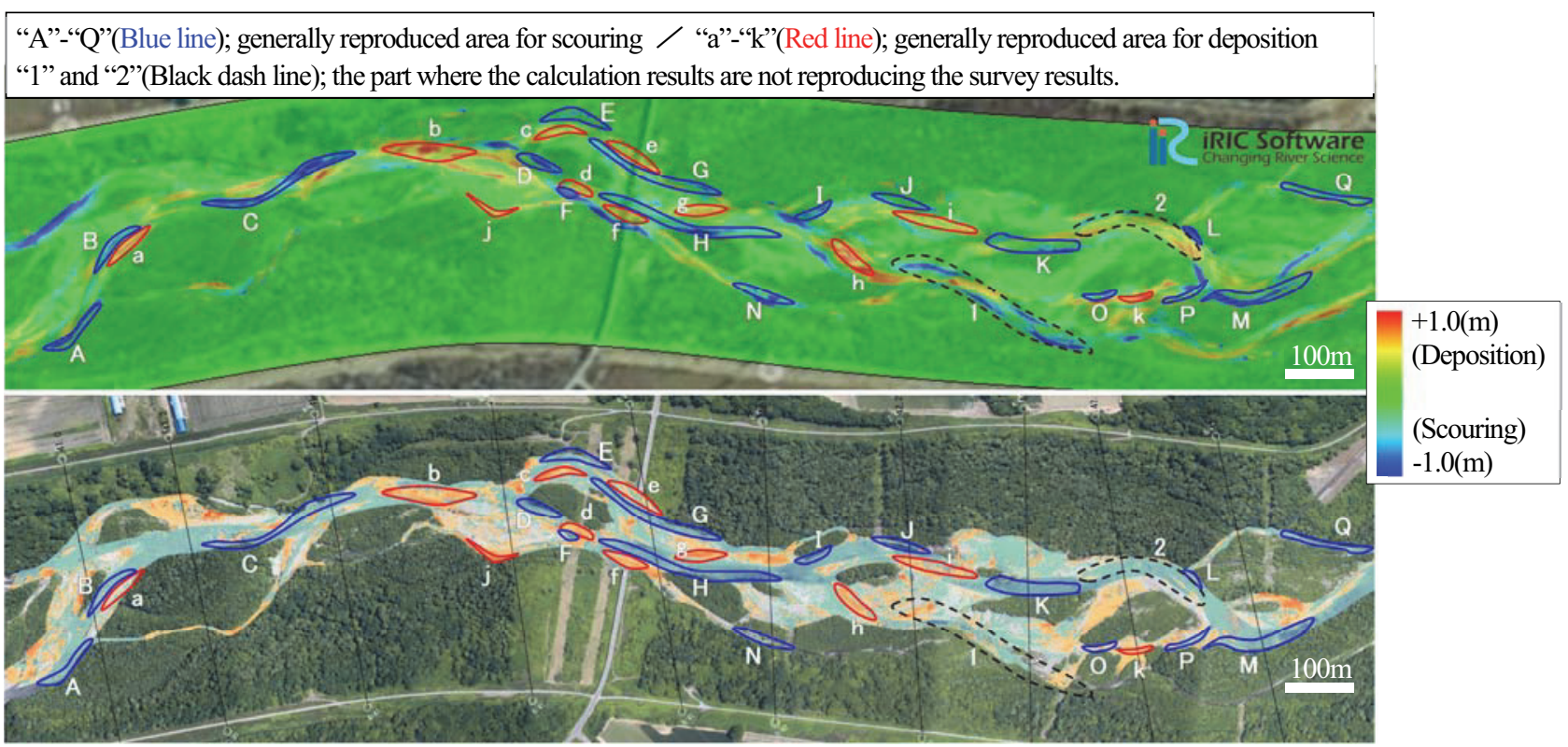

Fig.7 The riverbed shapes before and after the artificial flood when the bed material is $59.2 \mathrm{~mm}$ case (upper panel) and observed data (lower panel). 
diameter. Based on the results, section 1 in Fig. 7 shows more erosion than there really was and section 2 shows more deposition than what really happened. By excavating and connecting into the old watercourse, the flow into the watercourse increased tractive force and therefore caused advanced erosion in section 1. Meanwhile, the tractive force probably was lowered in the current watercourse and resulted in overall sediment deposition in section 2 .

As noted above, the simulation did not replicate what happened exactly; however, the trend in erosion in the flow convergent part and nearby deposition trend were generally replicated. In the old watercourse of about $10 \mathrm{~m}$ in width, bed variation scale is small, sections from $\mathrm{N}$ and $\mathrm{Q}$ and also $\mathrm{J}$ and $\mathrm{K}$ generally are confirmed to be replicated in both erosion and deposition trend. Therefore, grain diameter of $59.2 \mathrm{~m}$ will be used in the simulation calculation.

\section{(2) Prediction for maintenance of the old water- course by artificial flood}

Prediction calculation was implemented geographically after excavation for the old watercourse was connected with discharge conditions with or without artificial flood. All discharge conditions are shown in Fig. 8 (a) and Fig. 8 (b). Upon predicting the bed variations in the old watercourse, with its width being narrow about $10 \mathrm{~m}$, it was therefore divided into five meshes laterally and the grid size was set at $2 \mathrm{~m} \times$ $2 \mathrm{~m}$. However, the grid size was so small; thus, there were some issues in calculation in terms of calculation time. Therefore, the calculation section was set short between KP42 and 43. All calculation conditions are set the same as in Table 1 except discharge volume, grid size, and grid range. The stream profile after excavation in the E project area and estimated dimensionless tractive force $\tau_{*}$ are shown in Fig. 9. In calculating $\tau_{*}$, the river level and energy grade were calculated values and the representative diameter used for bed material was $59.2 \mathrm{~mm}$, which was the most replicable. As a result of the calcula-

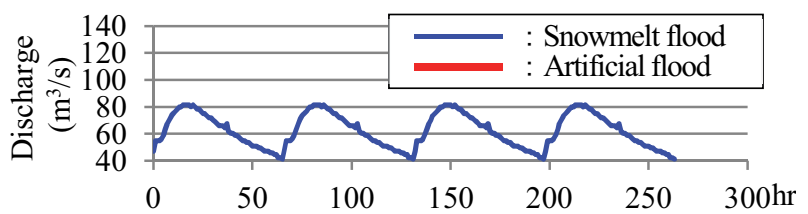

(a) Case $1:$ without artificial flood

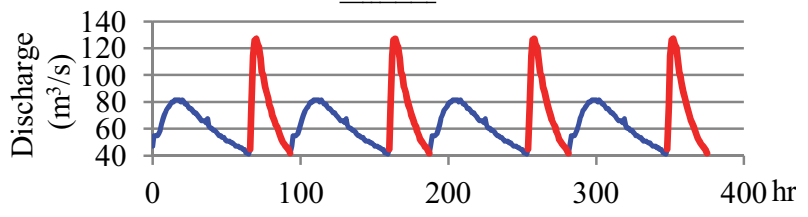

(b) Case 2 : with artificial flood

Fig.8 The discharge conditions for prediction calculations. tion, the discharge conditions estimated, $\tau_{*}$ being at or more than 0.05 , at which the bed materials are generally considered to start to move, are about $120 \mathrm{~m}^{3} / \mathrm{s}$ at the excavation point of connection at the old watercourse, and the lower reach in the old watercourse are estimated to be $80 \mathrm{~m}^{3} / \mathrm{s}$.

When artificial flood was not implemented, as indicated in Fig. 10 (a) and Fig. 11 (a), the inflow section in the old watercourse was maintained, and the sections within the old watercourse showed signs of sediment deposition. In the meantime, when artificial flood was implemented, as noted in Fig. 10 (b) and Fig. 11 (b), the inflow section at the old watercourse and its lower reach section was eroded and formed multiple channels with clear inflow into the old watercourse. Flow volume gradually decreases in floods from melted snow discharge, and in low-velocity sections and shallow areas, sediment deposition is likely.

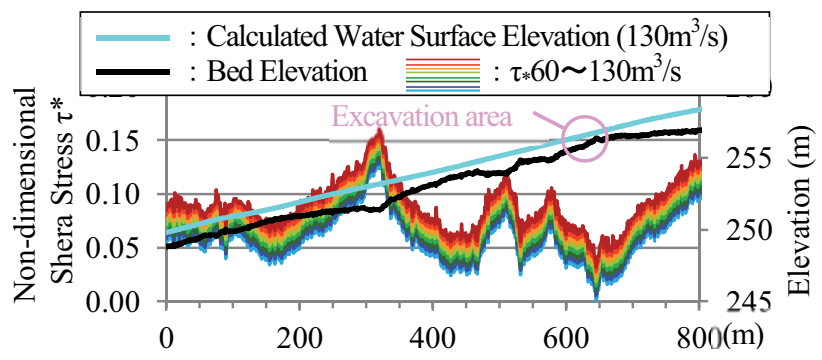

Fig.9 The longitudinal profile of the riverbed and the calculated dimensionless shear stress $\tau_{*}$ immediately after excavation of the old watercourse entrance at KP42.6.

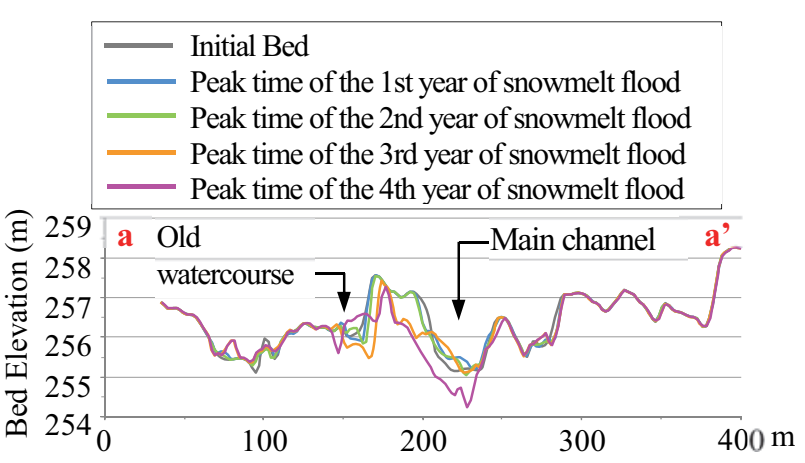

(a) Case $1:$ without artificial flood

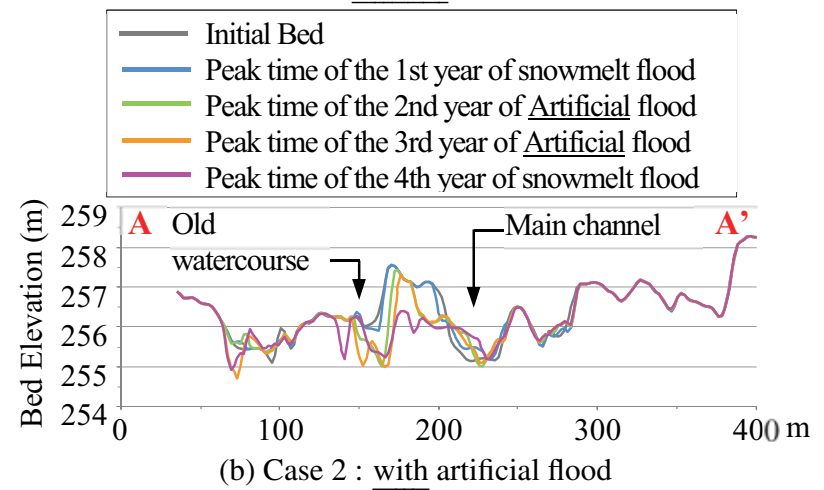

Fig.10 Calculated result of the cross section at KP42.6. 

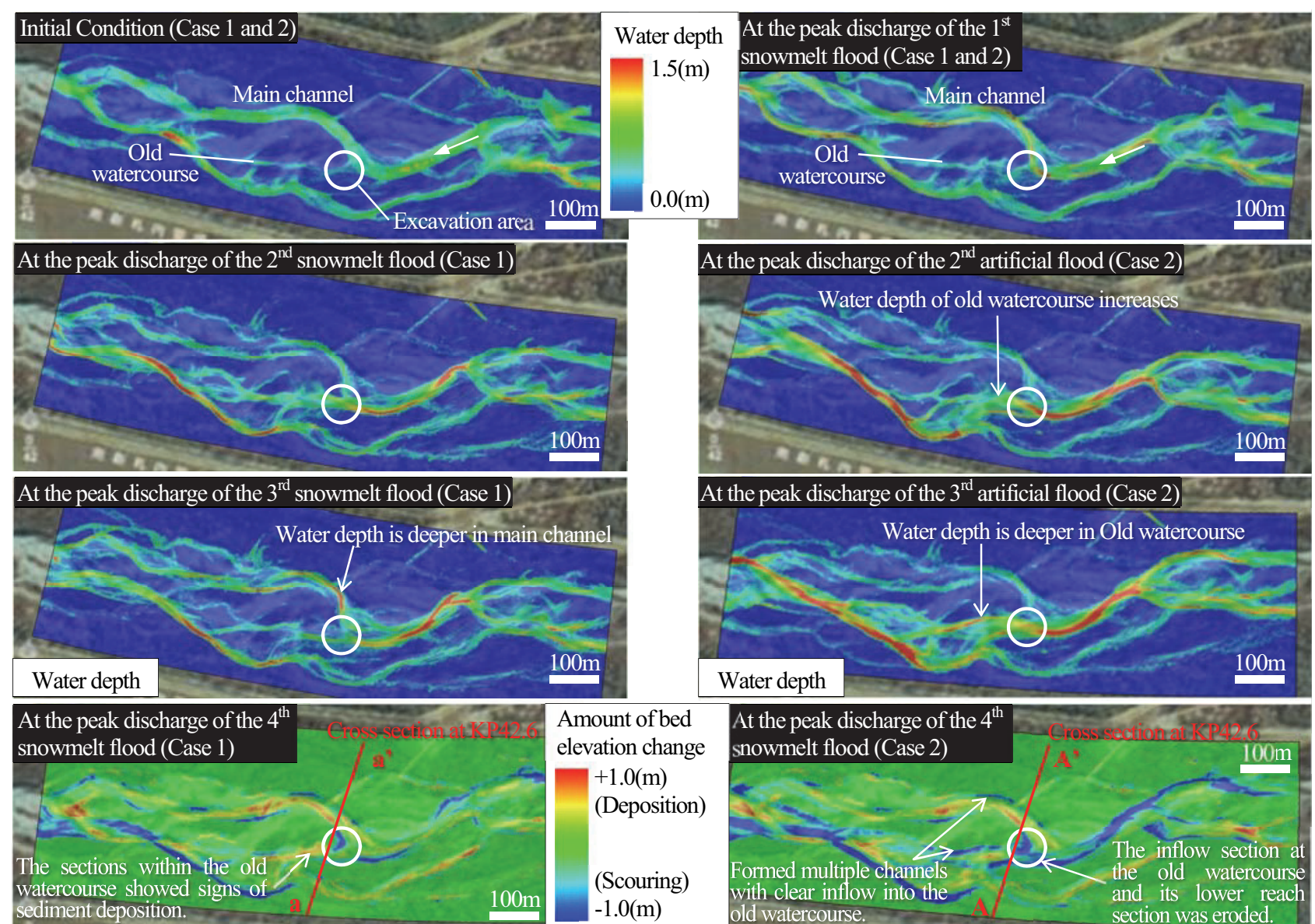

Amount of bed elevation change

(a) Case $1: \underline{\text { without artificial flood }}$

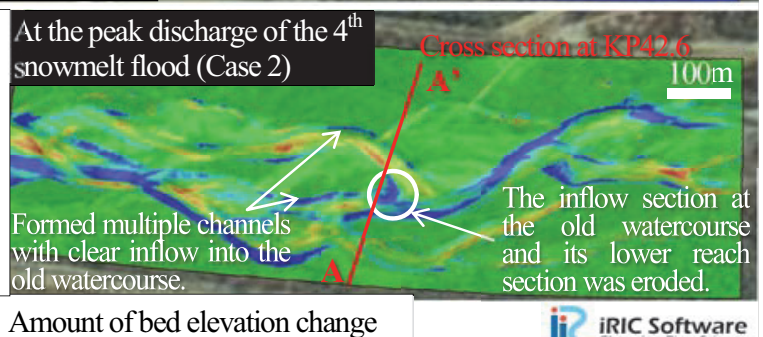

(b) Case $2:$ with artificial flood

Fig.11 Calculated results.

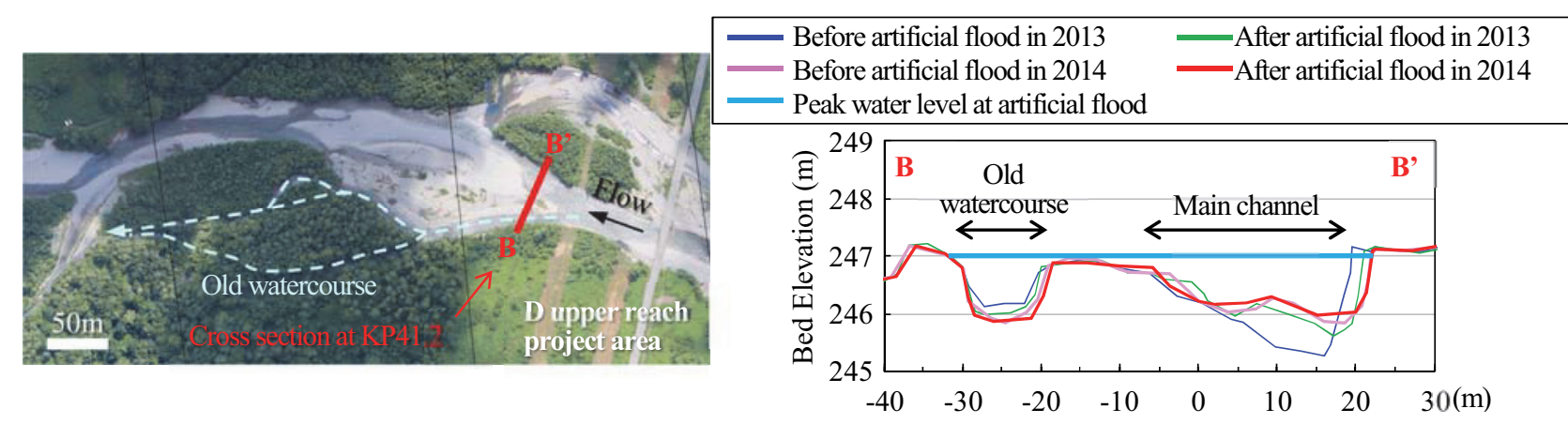

Fig.12 The secular changes in actual topography at KP41.2 due to artificial floods.

Artificial floods, which have a greater peak flow with greater fluctuations, and rapid bed fluctuations contributed more sedimentation than erosion in the old watercourse and therefore the old watercourse was maintained.

Compared with single channel, the current watercourse tends to have sediment deposition as a result of branches into the old watercourse, which lowers tractable force. Fig. 12 shows the actual geographical changes at KP 41.7 as time series. The difference in the heights within the channel is reduced and we could expect the formation of multiple channels that could easily lead to alternation. ${ }^{9)}$

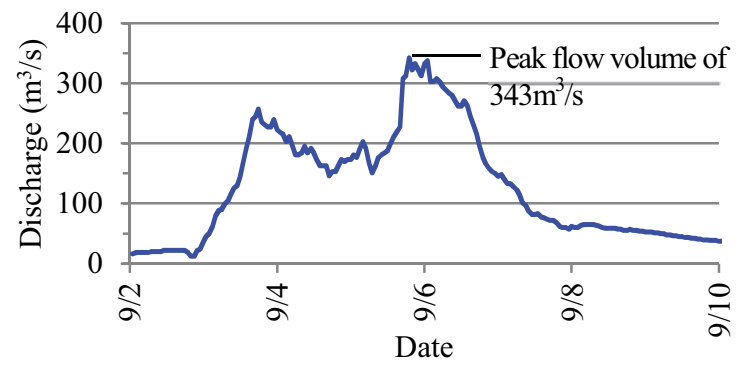

Fig.13 The hydrograph of the 2011 flood (probability scale of $1 / 20$ ). 
(3) Prediction of positive effects expected with the maintenance of the old watercourse

To determine the effects of artificial large-scale flood in maintaining the old watercourse, we predicted flow variation differences at the channel where inflow into the old watercourse was blocked (geographical condition 1) and at the channel where the flow after excavation into the old watercourse (geographical conditions 2). In this prediction calculation, we applied the flow volume of $343 \mathrm{~m}^{3} / \mathrm{s}$ of hydrology using the flood performance recorded in September 2011. The conditions are the same as noted in Table 1 except the flow volume and the geographical conditions at the inflow section into the old watercourse.

Bed variation range was limited when the flow into the old watercourse was blocked, as noted in Fig. 14 (a). In the case where multiple channels were formed by excavation into the old watercourse, as noted in Fig. 14 (b), a large-scale sediment erosion was seen in the current channel as well as in the old watercourse at the E project area and was noted in the lower reach area and channel variation toward the lower reach in the right bank. Additionally, at the convergent section of the E project excavation point, bank erosion moved up the channel in the left bank and a large channel change was seen as well.

\section{(4) Evaluation of the effects expected with the maintenance of the old watercourse}

Comparing the aerial photographs of the pre and post peak discharge of about $291 \mathrm{~m}^{3} / \mathrm{s}$ of August 2014 flood and the largest-scale flood in August 2016 (discharge undetermined), we confirmed, as shown in Fig. 15 and Fig. 16, at the E project area, that in real flood, there was a similar channel change as seen in
Fig. 14 (b), which changes the channel to lower reach right bank direction by eroding both the left bank of the inflow section of the old watercourse and its lower side along the old watercourse.

Next, we compared the aerial photographs of pre and post flood of August 2016 at the project areas installed after 2015 and we noted, as shown in Fig. 17, a large-scale erosion along the old watercourse at the $\mathrm{H}$ project area. At the $\mathrm{J}$ project area, the flood flow entered from the excavation and connection point and flowed directly into the right bank and large-scale erosion occurred. At the $\mathrm{K}$ project area, a series of erosion was seen along the old watercourse although the scale was smaller than those seen in other project areas.

To understand the effects of maintenance of the old watercourse, as shown in Fig. 16 and Fig. 17, the vegetative areas lost after the flood in August 2016 were sectioned by the old and the current watercourses and the areal totals were tallied within the sections of the entire upper reach and the old watercourse that was connected. Fig. 18 shows the data extraction method in the project areas and Fig. 19 shows the results from the areas tallied. As to the vegetative areas lost per $1 \mathrm{~km}$ of channel, in the upper reach section of about $24.0 \mathrm{~km}$, the areas along the old watercourse had 3.7 ha lost, which is about 2.2 times more than that in the current channel of $1.7 \mathrm{ha}$. In the project areas of about $3.8 \mathrm{~km}$, on the other hand, the old watercourse had lost 4.1 ha, which is about 3.7 times more than that of current channel lost, which was 1.1 ha, and the project areas had more vegetative areas lost than the old watercourse did.

Based on this investigation, we found that the old watercourse tended to lose more vegetative areas ow-

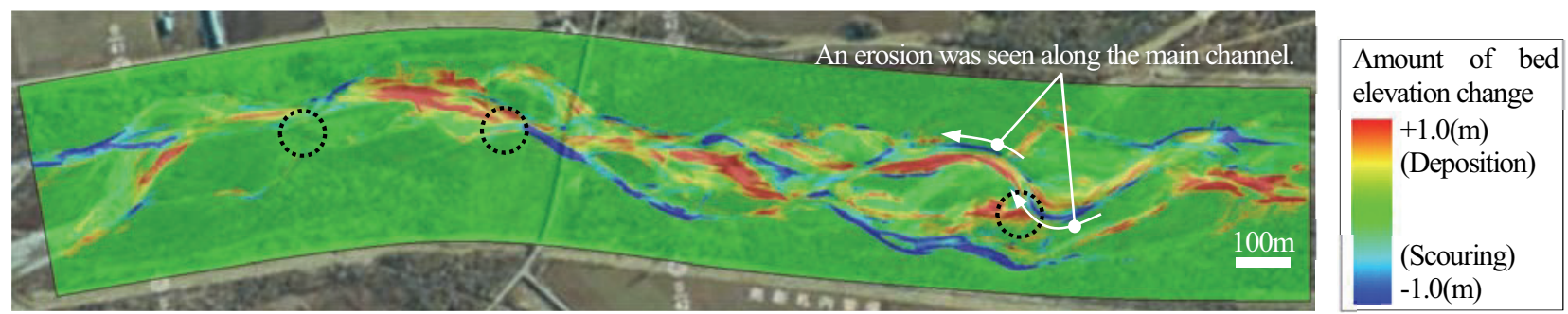

(a) geographical condition $1:$ the topographical condition in which the entrance of the old watercourse was closed

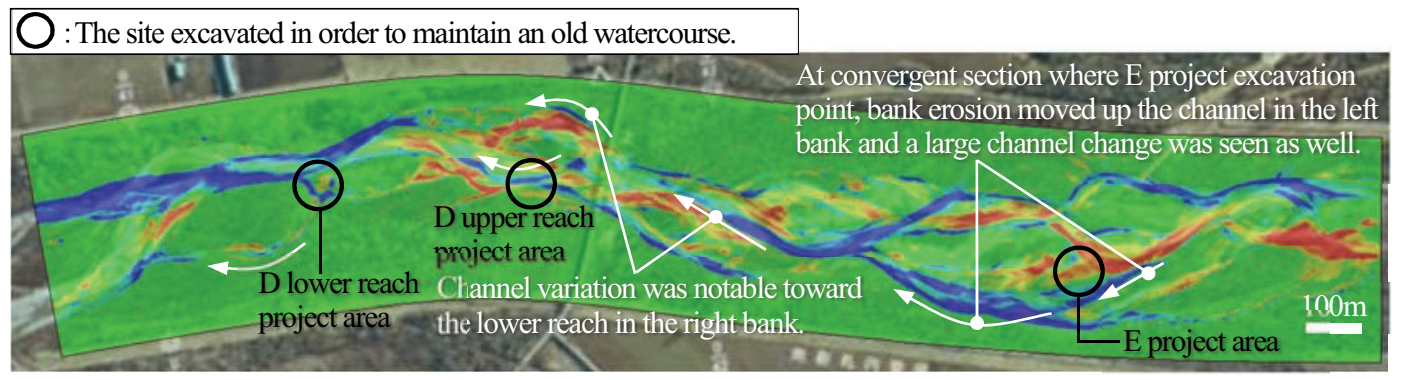

(b) geographical condition $2:$ the topographical condition in which the entrance of the old watercourse was excavated

Fig.14 Calculated results. 


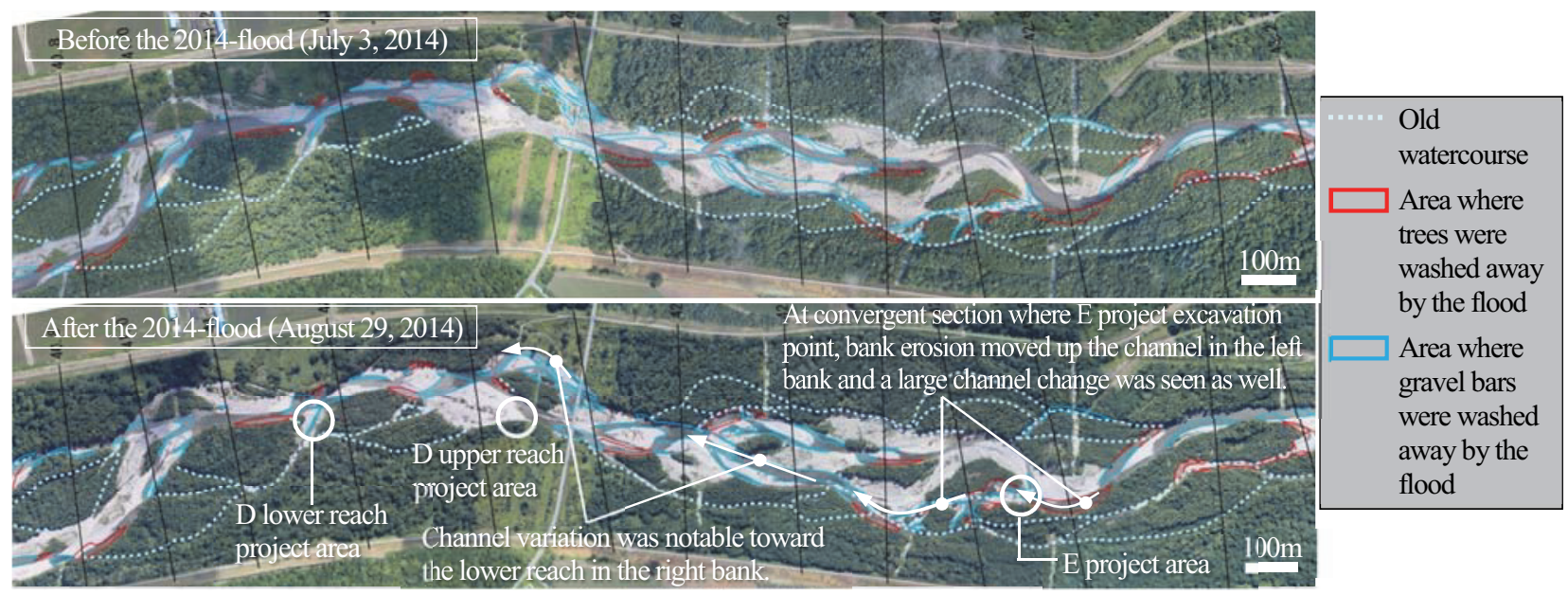

Fig.15 The change situation of the channel shape by the 2014-flood (D lower reach, D upper reach and E project area).

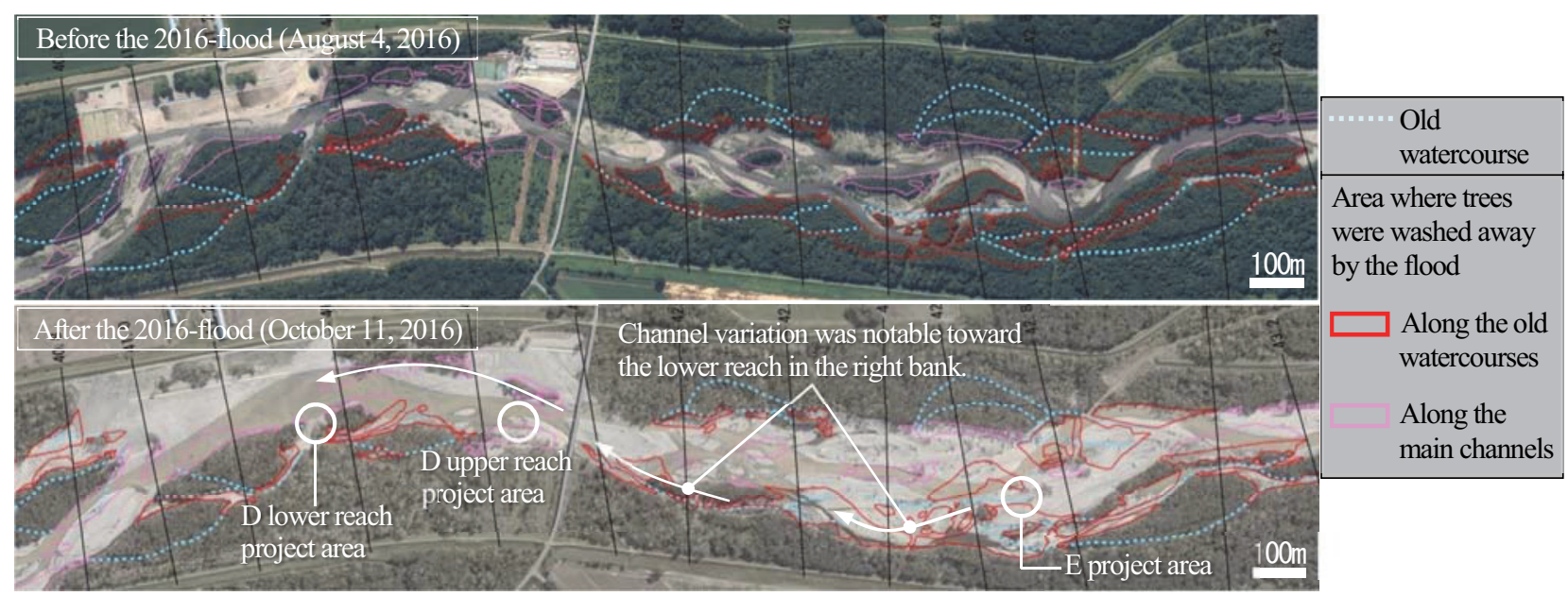

Fig.16 The change situation of the channel shape by the 2016-flood (D lower reach, D upper reach and E project area).

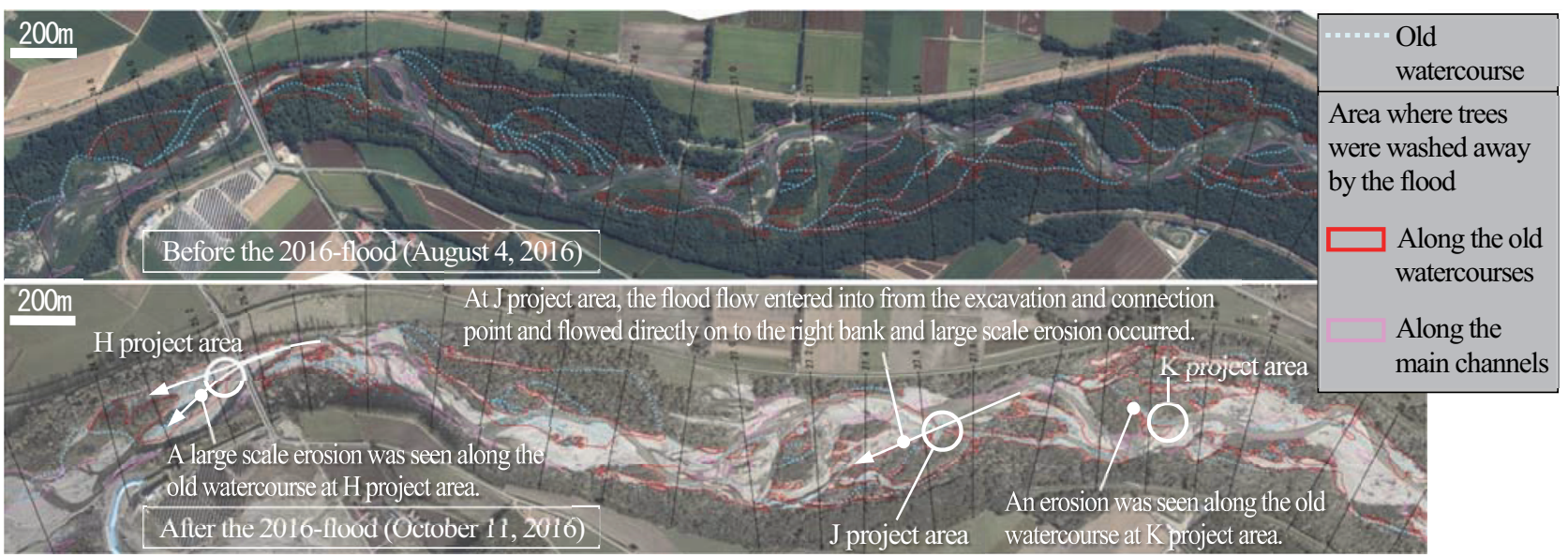

Fig.17 The change situation of the channel shape by the 2016-flood (H, J and E project area).

ing to the floods than the current watercourse. Likewise, in the areas we intentionally maintained by excavation and artificial floods in the old watercourse, the tendency was more significant during the floods. Therefore, we found that maintenance of old watercourse, by promotion of channel changes during floods, contributes to the loss of vegetative areas and thus has positive impacts in the recovery of gravel bars.

\section{CONCLUSION}

This study showed the following:

- In the channel with continuous nodes and antinodes, nodes were classified as pools and antinodes as riffles. The distribution of old watercourse and the location of nodes and antinodes were confirmed through existing aerial photographs. Understanding the stream profile 


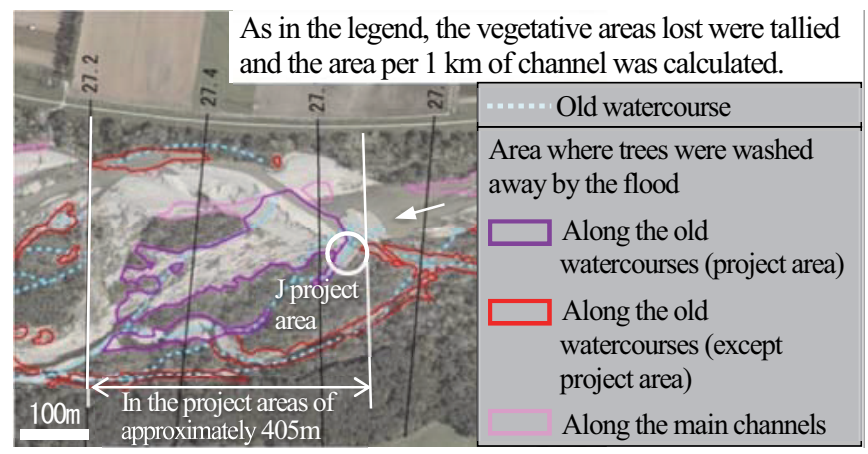

Fig.18 Method for extracting area where trees were washed away in the project areas (Example of $\mathrm{J}$ project area).

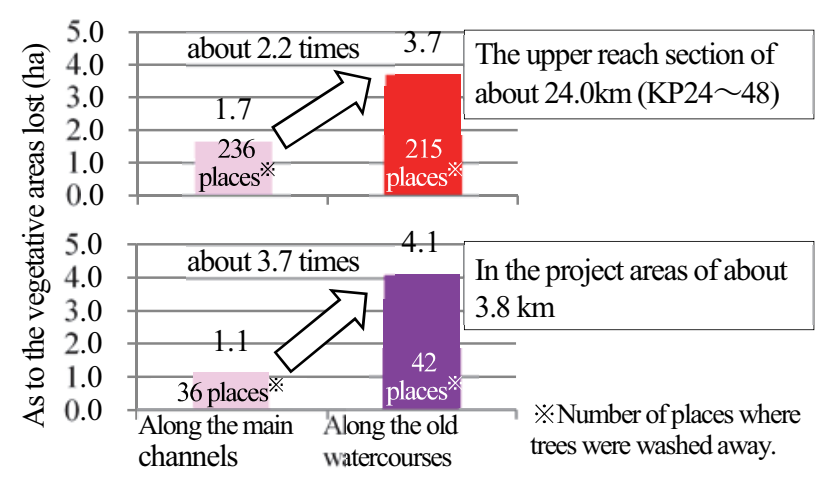

Fig.19 As to the vegetative areas lost per $1 \mathrm{~km}$ of channel.

in the upper and lower sections of the nodes were done through detailed survey, which revealed the longitudinal characteristics of pools and riffles. Then, excavation into the old watercourse at immediate lower nodes contributed to the efficiency of the survey and restoration works on multiple channels.

- The artificial floods implemented to restore gravel bars in the Satsunai River have positive impacts in maintaining the old watercourse by excavation and connection into it and reducing the difference in the heights within the channel. By this we could expect the formation of multiple channels that can easily lead to alternation. ${ }^{9)}$

- Based on the prediction of positive impacts expected by maintaining the old watercourse using river bed variation calculation, channel changes were analyzed during the flood in August 2016, which was the largest available scale. Results showed that the vegetative areas lost owing to the flood tended to be larger along the old watercourse than they were in the current channel, and in the sections where the old watercourse was actively maintained by excavating into it, the tendency to increase vegetative areas lost was noticeable.

- It was demonstrated that the maintenance of the old watercourse had positive impact on the restoration of gravel bars by promoting channel changes during floods.

ACKNOWLEDGMENT : Restoration of the Satsunai River gravel bars is moving forward with much advice and cooperation from "The Satsunai River Technical Committee" members and many others. This study was supported by the Ministry of Land, Infrastructure, Transport and Tourism River Erosion and Sediment Control Technical Research Development's public participated local issue area "River Environment Network continuity and time/space changes (Leader: Futoshi Nakamura)" and Grant for Scientific Research "Elucidation on Continuous Node and Anti-node Channel Formation Mechanism (Leader: Yasuharu Watanabe)". We thank them for their support.

\section{REFERENCES}

1) Takahashi, T., Homura, K. and Takeda, A. : On Gravel Bar Restoration in the Sattsunai River, Hokkaido Development Bureau Technical Research Symposium, 2015.

2) Obihiro Development and Construction Dept. : Observation Report on Artificial Flood, Hokkaido Development Bureau, Ministry of Land, Infrastructure, Transport and Tourism (in Japanese).

3) Yamaguchi, S., Watanabe, Y., Takahashi, T. and Sumitomo, K. : Effective Excavation for Restoring the Former Watercourses of a River where the Watercourses are Established, Proceedings of the 11th International Symposium on Eco-hydraulics, Paper No. 25936, 2016.

4) Shimizu, Y., Iwami, S., Ishikawa, Y., Sato, F., Isoda, T. and Endo, T. : Study on Restoration for Reproducing Gravel Bars in a Forested River by Using Flood Disturbance, JSCE Proceedings of River Engineering, Vol. 14, pp. 169-174, 2008.

5) Matsuda, K., Sudo, T., Uchibori, S., Oshima, H., Shimizu, Y. and Todo, M. : Study on Riverbed Deformation Caused by Flood Disturbance Resulting from Channel Excavation and Forestation Control Measures on a Stable Gravel Bars (Part 2), JSCE Proceedings of River Engineering, Vol. 17, pp. 233-238, 2011.

6) Watanabe, Y., Kawagishi, H and Sumitomo, K. : Methods on Restoration of Branch Rivers in the Artificial Discharge in the Satsunai River, 18th Ecology and Civil Engineering Society Conference Papers, pp. 275-278, 2014.

7) Watanabe, Y., Hasegawa, K., Yoshikawa, Y. and Hayakawa, H. : Linear Stability Analysis on Channel with Periodic Width Variations, JSCE Proceedings of Hydraulic Engineering, Vol. 70, No. 4, pp. I_991-I_996, 2014.

8) http://i-ric.org/ja/

9) Hasegawa, K., Hirose, K. and Meguro, E. : Experiments and Analysis on Alternating Mainstream Change in the Bifurcated Channel in Mountain rivers, JSCE Proceedings of Hydraulic Engineering, Vol. 47, pp. 679-684, 2003.

(Received January 10, 2018) 